\title{
Population genetic structure based on mitochondrial DNA analysis of Ikonnikov's whiskered bat (Myotis ikonnikovi-Chiroptera: Vespertilionidae) from Korea
}

\author{
Soyeon Park', Pureum Noh'², Yu-Seong Choi ${ }^{3}$, Sungbae Joo ${ }^{1}$, Gilsang Jeong ${ }^{4}$ and Sun-Sook Kim ${ }^{1 *}$
}

\begin{abstract}
Background: Ikonnikov's whiskered bat (Myotis ikonnikovi) is found throughout the Korean Peninsula, as well as in Kazakhstan, Russia, Mongolia, China, and Japan. It is small-sized and primarily inhabits old-growth forests. The decrease and fragmentation of habitats due to increased human activity may influence the genetic structure of bat populations. This study was designed to elucidate the population genetic structure of M. ikonnikovi using mitochondrial genes (cytochrome oxidase I and cytochrome b).

Results: The results showed that M. ikonnikovi populations from Korea have high genetic diversity. Although genetic differentiation was not detected for the $\mathrm{CO}$ gene, strong genetic differentiation of the Cytb gene between Mt. Jeombong and Mt. Jiri populations was observed. Moreover, the results indicated that the gene flow of the maternal lineage may be limited.

Conclusions: This study is the first to identify the genetic population structure of $M$. ikonnikovi. We suggest that conservation of local populations is important for sustaining the genetic diversity of the bat, and comprehensive studies on factors causing habitat fragmentation are required.
\end{abstract}

Keywords: Myotis ikonnikovi, Population structure, Genetic diversity, Cytochrome oxidase I, Cytochrome b

\section{Background}

Bats are small mammals found globally, except in polar regions, and have a high worldwide biodiversity of 1200 species (Schipper et al. 2008). Bats play important ecological roles, including in insect population control, seed dispersion, and pollination. Their voracious feeding significantly contributes to pest control as they consume over 30\% of their body weight in insects per night. Their roles in pest control and seed dispersion have been recognized for their economic value, and the importance of ecological services
* Correspondence: sskim108@nie.re.kr

${ }^{1}$ Evolutionary Ecology Research Team, National Institute of Ecology,

Seocheon 33657, Republic of Korea

Full list of author information is available at the end of the article provided by bats is being emphasized (Fenton 2003; Boyles et al. 2011; Kunz et al. 2011).

The distribution of Myotis ikonnikovi, a typical forest bat, spans from the Altai Mountains of Kazakhstan to the Siberian and Ussuri regions of Russia, southern Mongolia, northeastern China, Korea, and Honshu and Hokkaido of Japan (Simmons 2005). This species has been found in multiple areas of Korea, including Mt. Jeombong (JB), Mt. Odae (OD), Mt. Sobaek (SB), and Mt. Jiri (JR), where they roost in hollow trees or under the bark of living or dead trees in forests (Kim et al. 2014).

The home range of forest bats is associated with their weight (body size) (Fenton 1997). Species in the genus Myotis are mostly small and travel only a short distance from their roost site to foraging ground, and they use multiple roost sites within a relatively narrow home

(c) The Author(s). 2019 Open Access This article is distributed under the terms of the Creative Commons Attribution 4.0 International License (http://creativecommons.org/licenses/by/4.0/), which permits unrestricted use, distribution, and reproduction in any medium, provided you give appropriate credit to the original author(s) and the source, provide a link to the Creative Commons license, and indicate if changes were made. The Creative Commons Public Domain Dedication waiver (http://creativecommons.org/publicdomain/zero/1.0/) applies to the data made available in this article, unless otherwise stated. 
range (Kurta et al. 1996; Ormsbee 1996; Fenton 1997; Broders et al. 2006). Myotis ikonnikovi prefers mature forests that can satisfy its ecological needs regarding both food and shelter, and inhabits small areas within the habitat (Kim et al. 2014). Similarly to other Myotis species, this species changes its roost sites within a radius of $500 \mathrm{~m}$ or reoccupies previously abandoned roost sites (Lewis 1995; Brigham et al. 1997; Menzel et al. 2002; Kunz and Lumsden 2003; Kim et al. 2014).

The decrease and fragmentation of habitats due to increased human activity may influence the genetic differentiation of bat populations (Rossiter et al. 2000; Wright et al. 2018). We thus hypothesized that the Korean populations of $M$. ikonnikovi would be largely influenced by these factors, as the habitats of individual bats are usually within $0.5 \mathrm{~km}$ from their roost sites during their active periods (Kim et al. 2014). In this study, mitochondrial genes were analyzed to investigate the genetic diversity and differentiation among populations of M. ikonnikovi. Moreover, the study examined phylogenetic relationships among Russian, Chinese, and Japanese populations. The findings of the present study could be helpful for establishing efficient methods that consider genetic characteristics for the conservation management of M. ikonnikovi populations in Korea.

\section{Materials and methods \\ Collection of samples}

Forty-two M. ikonnikovi individuals were captured from six foraging sites in four regions (Mt. Jeombong, Mt. Odae, Mt. Sobaek, and Mt. Jiri) using mist nets from mid-May to early August in 2014 to 2016 (Table 1, Fig. 1). Tissue samples were collected from the chiropatagium of one wing of each bat using a 3-mm-diameter biopsy punch, and a ring band carved with a serial number was attached to a leg of each individual (Faure et al. 2009). After sampling, all bats were released at the capture site, and the tissue samples were stored in 100\% ethanol at $-20^{\circ} \mathrm{C}$.

\section{DNA extraction and amplification}

Genomic DNA was extracted from each tissue sample stored in 100\% ethanol using a DNeasy Blood and Tissue Kit (Qiagen, Hilden, Germany) according to the manufacturer's instructions and stored at $-20^{\circ} \mathrm{C}$. To amplify the two target mitochondrial regions $\mathrm{COI}$ and Cytb, universal primers (LCO1490-HCO2198 for COI, L14724-MVZ16 and L15162-H15915 for Cytb) and an M. ikonnikovi-specific primer that was designed for the present study were used (Additional file 1: Table S1). The specific primers (MICOI-F, -R and MICytbL-F, -R) were designed for more effective PCR amplification based on the sequences of the PCR products that were amplified using the universal primer sets. The $C y t b$ gene sequence was divided into two parts to facilitate the PCR amplification and sequencing. The fore part was amplified using the L14724-MVZ16 or MICytbFMICytbR primer sets, and the rear part was amplified using the L15162-H15915 primer set. PCR amplifications were performed using premixed ready strips (FastMix Frenche $^{\mathrm{Tw}}$ PCR i-Taq, iNtRon Biotechnology, Seongnam, Republic of Korea) with $16 \mu$ l distilled water, $1 \mu \mathrm{l}(10 \mathrm{pmol})$ of each primer, and $2 \mu \mathrm{l}$ template DNA. All PCR amplifications were conducted in a PeqSTAR Universal Gradient thermocycler (Peqlab GmbH, Erlangen, Germany). The temperature profile included an initial denaturation step of $3 \mathrm{~min}$ at $94{ }^{\circ} \mathrm{C}$ followed by 35 cycles of $1 \mathrm{~min}$ at $94^{\circ} \mathrm{C}, 1 \mathrm{~min}$ at each annealing temperature (Additional file 1: Table S1), 1 2 min at $72^{\circ} \mathrm{C}$, and a final extension step of $5 \mathrm{~min}$ at $72^{\circ} \mathrm{C}$.

The PCR amplicons were separated and visualized using 1\% agarose gel electrophoresis with TopGreen Nucleic Acid Gel Stain (Genomic Base, Seoul, Republic of Korea) and then purified using a Fragment DNA purification kit (iNtRon Biotechnology) for sequencing. The purified PCR products were read in both directions.

\section{Population genetic and phylogenetic analyses}

The resultant sequences were assembled and edited with the ClustalW algorithm embedded in MEGA7 software

Table 1 Sampling sites of Myotis ikonnikovi in Korea

\begin{tabular}{|c|c|c|c|c|c|}
\hline Population & Sample size & Date & Site & Latitude & Longitude \\
\hline \multirow[t]{2}{*}{ Mt. Jeombong (JB) } & 5 & 16 Jun 2016 & \multirow{2}{*}{$\begin{array}{l}\text { Jindong-ri, Girin-myeon, Inje-gun, } \\
\text { Gangwon-do, Korea }\end{array}$} & \multirow[t]{2}{*}{$38.043960 \mathrm{~N}$} & \multirow[t]{2}{*}{$128.474633 \mathrm{E}$} \\
\hline & 1 & 17 Aug 2016 & & & \\
\hline \multirow[t]{2}{*}{ Mt. Odae (OD) } & 15 & 31 Jul 2014 & \multirow{2}{*}{$\begin{array}{l}\text { Dongsan-ri, Jinbu-myeon, } \\
\text { Pyeongchang-gun, Gangwon-do, Korea }\end{array}$} & \multirow[t]{2}{*}{$37.765082 \mathrm{~N}$} & \multirow[t]{2}{*}{$128.577128 \mathrm{E}$} \\
\hline & 12 & 1 Aug 2014 & & & \\
\hline \multirow[t]{2}{*}{ Mt. Sobaek (SB) } & 3 & 24 May 2014 & \multirow{2}{*}{$\begin{array}{l}\text { Jwaseok-ri, Dansan-myeon, } \\
\text { Yeongju-si, Gyeongsangbuk-do, Korea }\end{array}$} & \multirow[t]{2}{*}{$37.008669 \mathrm{~N}$} & \multirow[t]{2}{*}{$128.585180 \mathrm{E}$} \\
\hline & 1 & 14 Aug 2015 & & & \\
\hline \multirow[t]{2}{*}{ Mt. Jiri (JR) } & 4 & $12 \mathrm{Jul} 2014$ & $\begin{array}{l}\text { Jungsan-ri, Sicheon-myeon, Sancheong-gun, } \\
\text { Gyeongsangnam-do, Korea }\end{array}$ & $35.320792 \mathrm{~N}$ & $127.755091 \mathrm{E}$ \\
\hline & 1 & 13 Jul 2014 & $\begin{array}{l}\text { Naedong-ri, Toji-myeon, Gurye-gun, } \\
\text { Jeollanam-do, Korea }\end{array}$ & $35.268310 \mathrm{~N}$ & $127.576770 \mathrm{E}$ \\
\hline
\end{tabular}




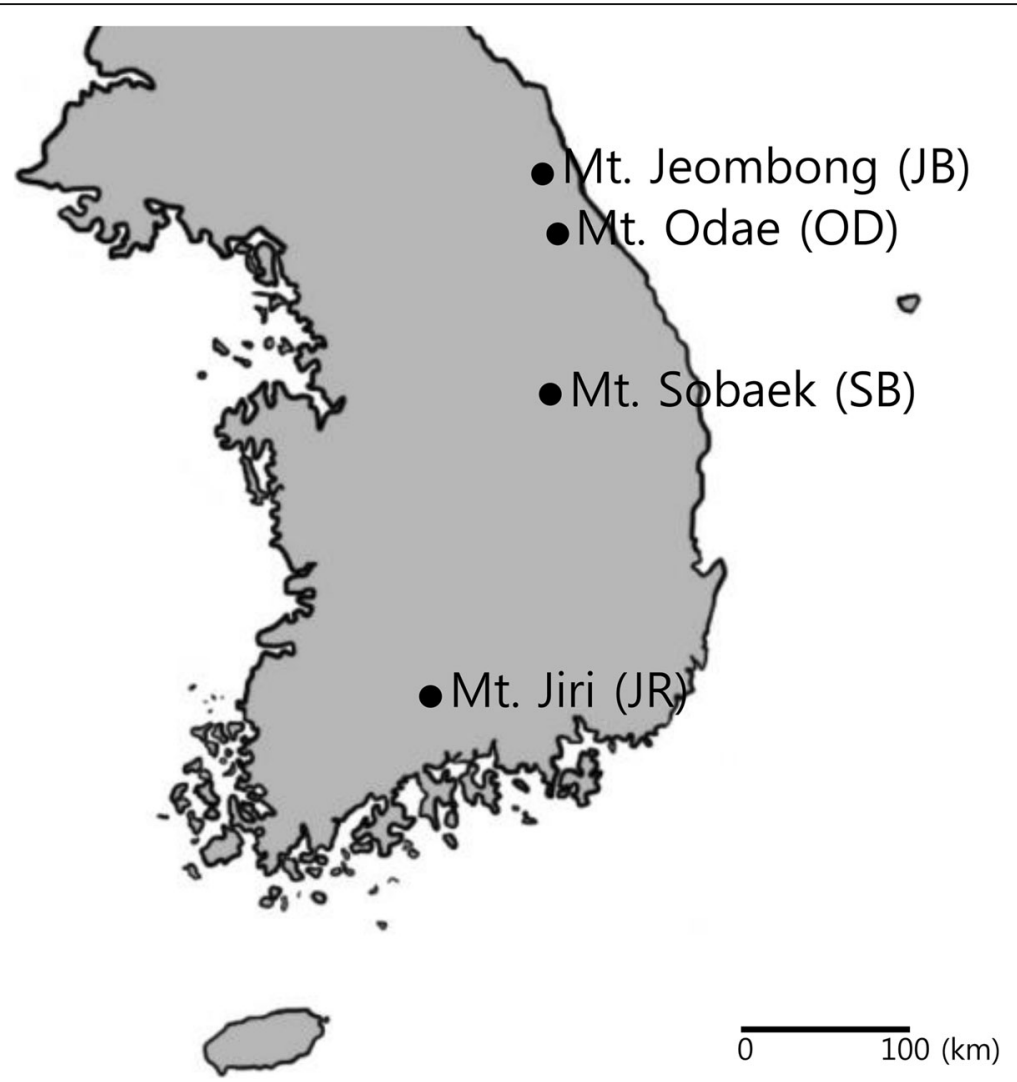

Fig. 1 Map of sampling sites of populations of Myotis ikonnikovi in Korea

(Kumar et al. 2016). The haplotypes of each gene were determined using DnaSP v5 (Librado and Rozas 2009). For population genetic analyses, samples were assorted into four mountain populations according to collection sites (Table 1). The network relationships among the haplotypes were inferred with the median-joining algorithm and were visualized in Network 5.0 (Bandelt et al. 1999). The haplotype network was reconstructed with the regional data in PowerPoint 2013 (Microsoft, Redmond, WA, USA).

Molecular diversity indices were generated for four populations and each gene using ARLEQUIN (Excoffier and Lischer 2010). For comparing populations with different sample sizes, haplotype richness $\left(H_{R}\right)$ was calculated after rarefaction based on the smallest sample size (ADZE 1.0) (Szpiech et al. 2008). The population genetic structure and neutrality of populations were tested by analysis of molecular variance (AMOVA), including the overall fixation index statistics $\left(F_{\mathrm{ST}}\right)$ and pairwise $F_{\mathrm{ST}}$ with 1000 permutations, in ARLEQUIN. The Mantel test was used to test isolation by distance (IBD) between geographical distance and pairwise $F_{\mathrm{ST}}$ in ARLEQUIN.

Maximum-likelihood (ML) trees for the haplotypes of two genes (COI, $597 \mathrm{bp}$ and Cytb, $1006 \mathrm{bp}$ ) were generated with 1000 bootstrap replicates after selecting the best-fit substitution model in MEGA7. The Tamura 3parameter+gamma $(\mathrm{T} 92+\mathrm{G})$ and Hasegawa-KishinoYano+gamma $(\mathrm{HKY}+\mathrm{G})$ models were selected for ML analysis of the $\mathrm{COI}$ and Cytb genes, respectively. For both phylogenetic trees, sequences of Myotis bombinus from the GenBank database were used as the outgroup. Because of limitations of genetic data availability, only the phylogenetic relationships among Russian, Chinese, and Korean populations for the COI gene and between Japanese and Korean populations for the Cytb gene were inferred.

\section{Results}

\section{Genetic diversity and haplotype network}

A total of 11 and 21 haplotypes were identified from the $\mathrm{COI}$ and $\mathrm{Cytb}$ genes, respectively (GenBank accession numbers MN528478-528561). The lowest haplotype diversity value for the $\mathrm{COI}$ gene was observed in the Sobaek (SB) population (0.5), and the highest was observed in the Jeombong (JB) population (0.8667). The lowest nucleotide diversity value was observed in the Jiri (JR) population (0.00163), and the highest was observed in the JB population (0.00878). For the Cytb gene, the SB haplotype diversity value was between 0.8 and 0.96 , and the nucleotide diversity value was between 0.00437 
Table 2 Molecular diversity indices of mitochondrial DNA across four populations of Myotis ikonnikovi in Korea

\begin{tabular}{|c|c|c|c|c|c|}
\hline Gene & & $J B(6)$ & OD (27) & SB (4) & JR (5) \\
\hline \multirow[t]{5}{*}{$\mathrm{COl}$} & $h$ & 4 & 7 & 2 & 3 \\
\hline & k & 10 & 10 & 6 & 2 \\
\hline & $H_{d}$ & 0.8667 & 0.8148 & 0.5 & 0.8 \\
\hline & $H_{R}$ & 3.2 & 3.02615 & 2 & 2.8 \\
\hline & $\pi$ & 0.00878 & 0.00540 & 0.00488 & 0.00163 \\
\hline \multirow[t]{5}{*}{ Cytb } & $h$ & 3 & 17 & 3 & 3 \\
\hline & k & 10 & 32 & 11 & 8 \\
\hline & $H_{d}$ & 0.8 & 0.9601 & 0.8333 & 0.8 \\
\hline & $H_{R}$ & 2.8 & 3.76746 & 3 & 2.8 \\
\hline & $\pi$ & 0.00530 & 0.00765 & 0.00580 & 0.00437 \\
\hline
\end{tabular}

$h$ number of haplotypes, $k$ number of polymorphic sites, $H_{d}$ haplotype diversity, $H_{R}$ haplotype richness, and $\pi$ nucleotide diversity

and 0.00765 , indicating similar haplotype and nucleotide diversity among the four populations (Table 2). Accounting for sample size, the highest haplotype richness of the COI and Cytb genes was observed in the JB population (3.2) and Odae (OD) population (3.76746), respectively (Table 2 ).

According to the haplotype network, the number of different nucleotides between haplotypes of COI was smaller than that between haplotypes of Cytb (Fig. 2). The JB and OD populations shared haplotypes in both genes (Fig. 2). In addition, specific haplotypes for each of the four populations appeared in both genes. In the COI gene, the OD population shared haplotypes with the remaining three populations. In the $C y t b$ gene, the JB and OD populations shared haplotypes with each other, while the SB and JR populations shared only a single haplotype. Conversely, the JR population did not share any haplotype with the JB or OD populations.

\section{AMOVA, IBD, and phylogenetic analysis}

The COI gene exhibited non-significant genetic differentiation among the populations $\left(F_{\mathrm{ST}}=0.01467, p>0.1\right)$, whereas the $C y t b$ gene exhibited high and significant differentiation among populations $\left(F_{\mathrm{ST}}=0.19769, p<0.01\right)$. However, in both genes, $>80 \%$ of the genetic variation was explained by differences among individuals within a population, while a small amount of the variation was attributable to differences among populations (Table 3). In the analysis of pairwise differences by population, the COI gene showed $F_{\mathrm{ST}}$ values ranging between -0.05719 and 0.17917 , whereas the genetic differentiation among

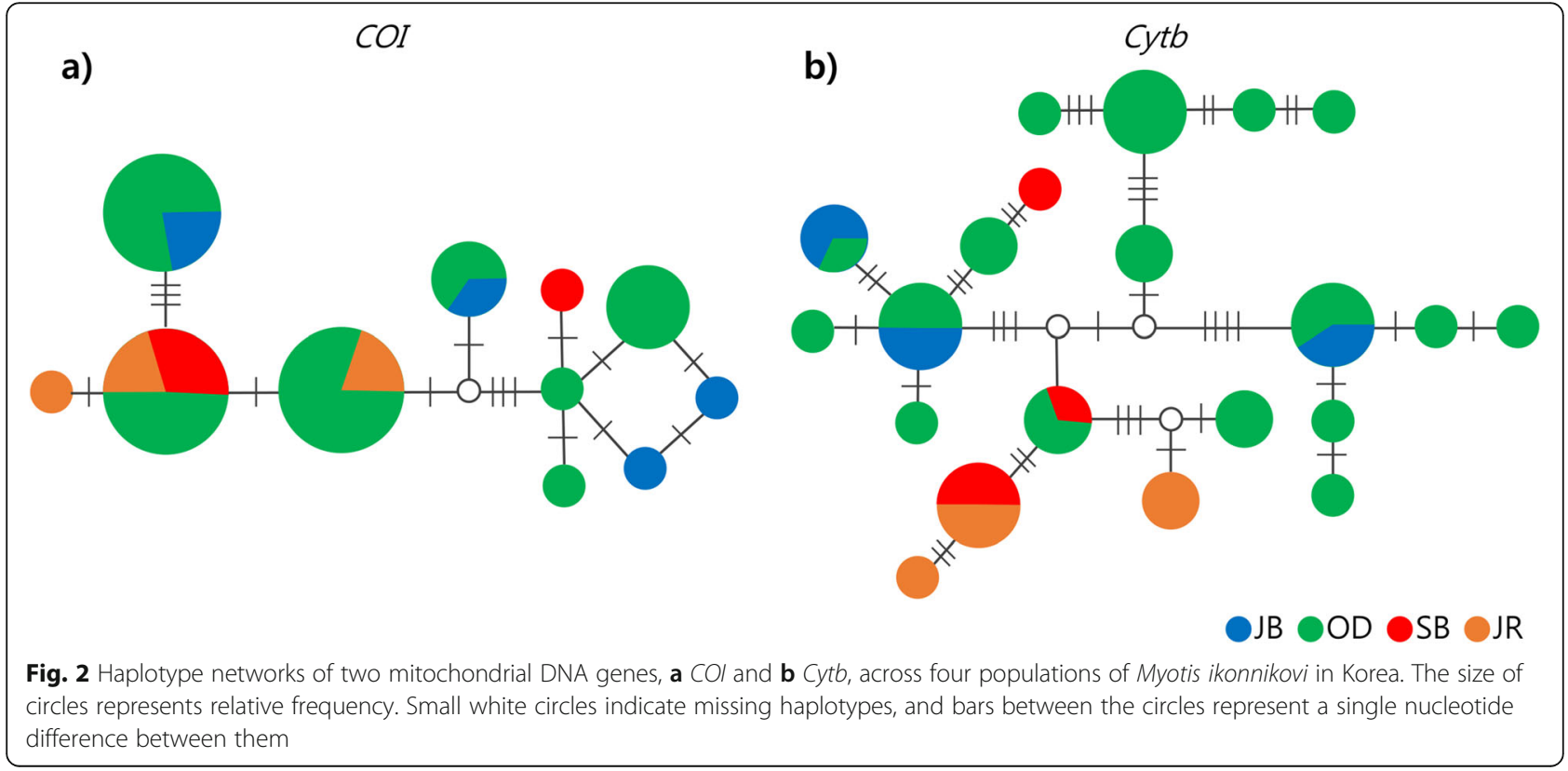


Table 3 AMOVA results for the COI and Cytb sequences of Myotis ikonnikovi in Korea

\begin{tabular}{llllll}
\hline Gene & Source of variation & d.f. & Sum of squares & Variance components & Percentage of variation \\
\hline COI & Among populations & 3 & 5.553 & 0.02475 & 1.47 \\
& Within populations & 38 & 63.185 & 1.66277 & 98.53 \\
& Total & 41 & & & \\
Cytb & F & $F_{\text {ST }}=0.01467, p$ value $>0.05$ & & \\
& Among populations & 3 & 29.699 & 0.84889 & 3.77 \\
& Within populations & 38 & 130.920 & 3.44527 & 4.29417 \\
& Total & 41 & 160.619 & & \\
\hline
\end{tabular}

all of the regions was not significant. Conversely, the $C y t b$ gene was significantly different between the JB and JR, OD and JR, and OD and SB populations (Table 4). The $F_{\mathrm{ST}}$ between JB and JR populations was the highest $\left(F_{\mathrm{ST}}=0.48594\right)$. In addition, Slatkin's linearized $F_{\mathrm{ST}}$ between JB and JR populations was the highest value (Additional file 1: Table S2). For the neutrality test of each population, the results were not significant, which indicated that the genetic diversity was achieved not by selection but by drift (Table 5 ).

The results of the Mantel test for both the COI and $C y t b$ genes, performed to investigate IBD, indicated that, even at far geographical distances, large genetic differentiation was not observed ( $C O I, p>0.1, r=-0.365$; $C y t b$, $p>0.1, r=0.506)$. While the genetic differentiation between JB and JR populations, which were farthest apart from each other, was highest, the correlations between geographical and genetic distances were not significant among other regions (Table 4).

According to the ML phylogenetic tree of the COI gene (597 bp), haplotypes appearing in the OD and JB populations clustered in the same clades as those from Russia (Fig. 3). This revealed that Korean populations might undergo genetic exchange with Russian populations. In phylogenetic trees of the Cytb gene, the haplotypes were divided into two clades (Fig. 3). One clade included only Korean haplotypes, while the other clade included Japanese haplotypes (Fig. 3). This could be

Table 4 Pairwise differentiation $\left(F_{S T}\right)$ for $\mathrm{COl}$ (above the diagonal) and for Cytb (below the diagonal) across four populations of Myotis ikonnikovi in Korea

\begin{tabular}{lllll}
\hline & JB & OD & SB & JR \\
\hline JB & & 0.01504 & -0.01408 & 0.17917 \\
OD & 0.05810 & & -0.05719 & 0.03300 \\
SB & 0.26821 & 0.14581 & & -0.02362 \\
JR & 0.48594 & 0.29715 & 0.03359 & \\
\hline
\end{tabular}

Italic values represent statistical significance at $p$ value $<0.05$ interpreted as an effect of geographical isolation between Korea and Japan. Our findings are similar to those reported for various bat species in Europe, including Myotis, which were genetically differentiated between populations from Britain and continental Europe (Atterby et al. 2010; Razgour et al. 2013; Moussy et al. 2015; Wright et al. 2018).

\section{Discussion}

We analyzed mitochondrial DNA markers to investigate the genetic diversity and differentiation among populations of M. ikonnikovi from Korea. The mitochondrial genes of $M$. ikonnikovi exhibited high genetic diversity. Although genetic differentiation was not detected for the COI gene, strong genetic differentiation between JB and JR populations was observed for the $C y t b$ gene. Moreover, the results of the present study indicated that the gene flow of the maternal lineage may be limited.

The genetic diversity of the Korean M. ikonnikovi populations based on Cytb sequences was higher than that calculated using COI sequences; this result is similar to that of Russian populations of Myotis dasycneme (Andersen et al. 2019). Other cases of high genetic diversity that are similar to that of the M. ikonnikovi populations herein include Myotis lucifugus and Myotis septentrionalis inhabiting North America; these species, however, were examined using the mitochondrial control region (Johnson et al. 2015). The average haplotype diversity (0.491) of European M. myotis using the mitochondrial control region was lower than that of $M$. ikonnikovi (Ruedi and Castella 2003). Therefore, the mitochondrial genetic diversity of Korean M. ikonnikovi is very high when compared with other Myotis species.

The closest populations (i.e., OD and JB) did not show any genetic differentiation, and the most distant populations (i.e., JB and JR) had the highest genetic differentiation. This result is consistent with the calculated IBD, which showed that genetic differentiation increases with greater distance. Interestingly, however, the SB 
Table $\mathbf{5}$ Tests of the model of neutrality across four populations of Myotis ikonnikovi in Korea

\begin{tabular}{|c|c|c|c|c|c|c|}
\hline Gene & & $\mathrm{JB}(6)$ & OD (27) & SB (4) & $J R(5)$ & Total (42) \\
\hline \multirow[t]{4}{*}{$\mathrm{COI}$} & Tajima's D & 1.39940 & 0.90959 & -0.80861 & 0.24314 & 0.33967 \\
\hline & & $p$ value $>0.1$ & & & & \\
\hline & Fu's FS & 1.32594 & 0.99739 & 2.94444 & -0.47542 & -0.91940 \\
\hline & & $p$ value $>0.1$ & & & & \\
\hline \multirow[t]{4}{*}{ Cytb } & Tajima's D & 1.30798 & -0.27061 & -0.27914 & 1.02753 & -0.39228 \\
\hline & & $p$ value $>0.1$ & & & & \\
\hline & Fu's FS & 3.11818 & -3.54325 & 1.74722 & 2.05468 & -3.65575 \\
\hline & & $p$ value $>0.1$ & & & & \\
\hline
\end{tabular}

population showed significant genetic differentiation over distance despite being closest to the OD population. Such genetic differentiation was also observed between the Mt. Odae and Mt. Sobaek populations of Rhinolophus ferrumequinum in Korea (Byeon et al. 2018).

The SB population appears to have participated in genetic exchanges with the JB population to the north and with the JR population to the south; this suggests that the SB population acts as a bridge between the northern and southern populations of M. ikonnikovi in Korea. Thus, the conservation of SB populations is particularly important for effective management of $M$. ikonnikovi in Korea. However, little is known regarding the SB population; therefore, further investigation of $M$. $i k o n n i k o v i$ in this area and in the area between the SB and JR populations is needed.

\section{Conclusions}

Myotis ikonnikovi is a small, nocturnal bat that forages within forests. These traits hamper the collection of the bats for population-level studies. Therefore, few population genetic studies at foraging sites have been performed, and little is known regarding the genetics of bat species from Northeast Asia (Kawai et al. 2003; Kruskop et al. 2012). This study is the first to identify the genetic

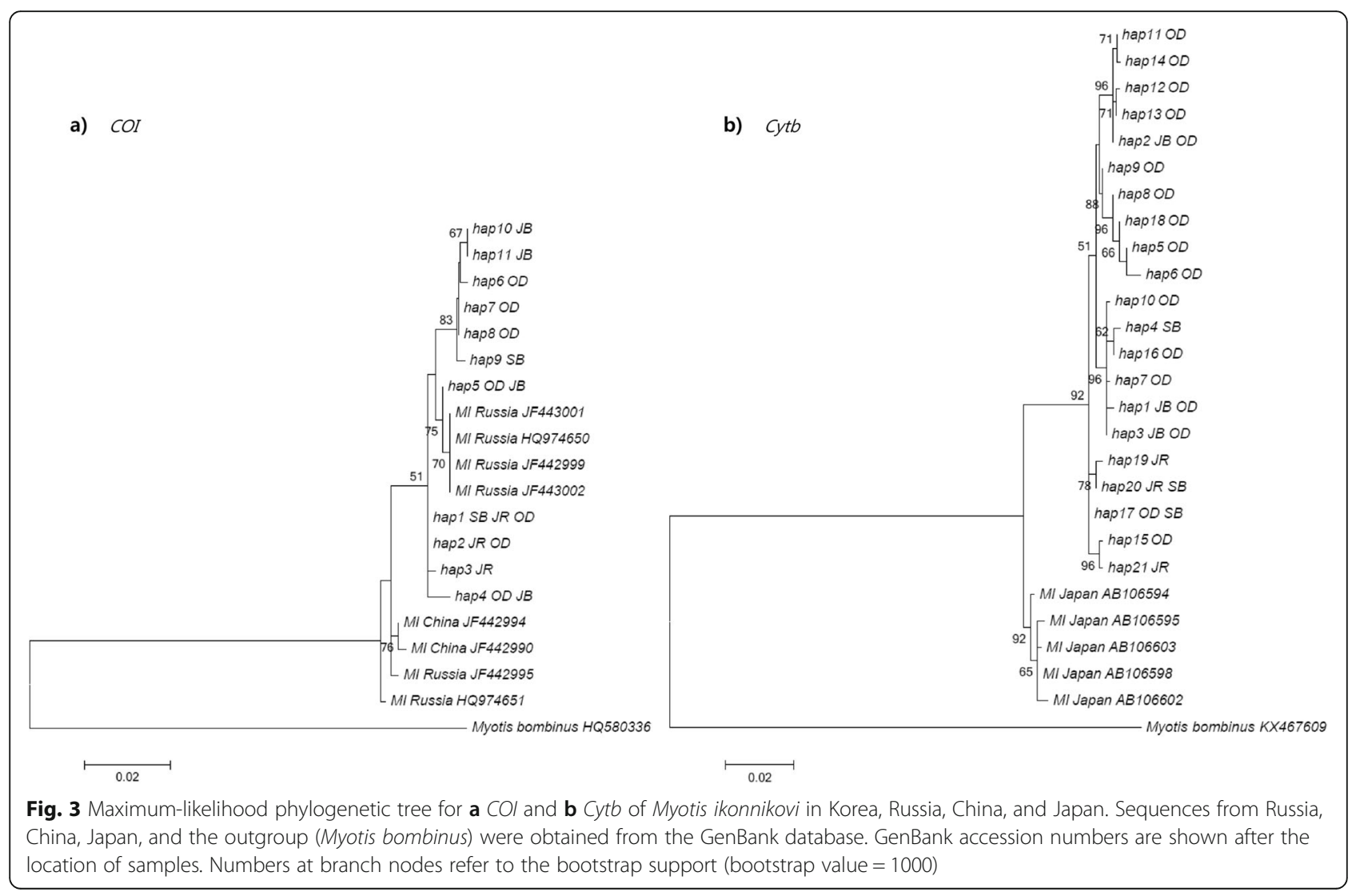


population structure of M. ikonnikovi, which is vulnerable to habitat fragmentation and loss as it inhabits oldgrowth forests of over 40 years of age (Kim et al. 2014). According to the results of the present study, the differentiation between local populations is evident; thus, we believe that all local populations should be individually preserved. Extensive research on factors causing habitat fragmentation will contribute to effective conservation and management of M. ikonnikovi populations in the future.

\section{Supplementary information}

Supplementary information accompanies this paper at https://doi.org/10. 1186/s41610-019-0140-5.

Additional file 1: Table S1. Primers used in the present study [Akmal et al. 2015; Irwin et al. 1991; and Vrijenhoek 1994]. Table S2. Slatkin's linearized $F_{S T}$ for COI (above the diagonal) and for Cytb (below the diagonal) across four populations of Myotis ikonnikovi in Korea.

\section{Abbreviations}

AMOVA: Analysis of molecular variance; COl: Cytochrome oxidase

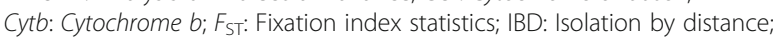
JB: Jeombong; JR: Jiri; ML: Maximum-likelihood; OD: Odae; SB: Sobaek

\section{Acknowledgments}

We thank Bong-Hyeon Kim, Seung-Hye Choi, and Dooly Jang for their devoted assistance throughout our fieldwork.

\section{Authors' contributions}

SP and PN contributed equally to this work. SSK designed the study and conducted the field study. YSC and SBJ collected the samples. SP and PN analyzed the data and wrote the manuscript. GJ reviewed the manuscript. All authors read and approved the final manuscript.

\section{Funding}

This study was supported by "Ecological roles and functions of insectivorous bats in Korea" through National Institute of Ecology (NIE-C-2019-02).

\section{Availability of data and materials}

The datasets generated and/or analyzed during the current study are available from the corresponding author on reasonable request.

\section{Ethics approval and consent to participate}

Not applicable

\section{Consent for publication}

Not applicable

\section{Competing interests}

The authors declare that they have no competing interests.

\section{Author details}

${ }^{1}$ Evolutionary Ecology Research Team, National Institute of Ecology, Seocheon 33657, Republic of Korea. ${ }^{2}$ Herbal Medicine Resources Research Center, Korea Institute of Oriental Medicine, Naju 58245, Republic of Korea. ${ }^{3}$ National Migratory Bird Center, National Institute of Biological Resources, Ongjin-gun, Incheon 23106, Republic of Korea. ${ }^{4}$ Long term Ecological Research Team, National Institute of Ecology, Seocheon 33657, Republic of Korea.
Received: 9 October 2019 Accepted: 4 December 2019

Published online: 30 December 2019

\section{References}

Akmali V, Mehdizadeh R, Chaghamirza K, Moradi M, Sharifi M. Taxonomic evaluation of the bent-winged bat (Miniopterus) populations occurring in Iran inferred from mitochondrial cytochrome-b sequences. Mammalia. 2015;79(4): 449-55.

Andersen LW, Dirksen R, Nikulina EA, Baagøe HJ, Petersons G, Estók P, et al Conservation genetics of the pond bat (Myotis dasycneme) with special focus on the populations in northwestern Germany and in Jutland. Denmark Ecol Evol. 2019;9(9):5292-308.

Atterby H, Aegerter JN, Smith GC, Conyers CM, Allnutt TR, Ruedi M, et al. Population genetic structure of the Daubenton's bat (Myotis daubentonii) in western Europe and the associated occurrence of rabies. Eur J Wildl Res. 2010;56(1):67-81.

Bandelt HJ, Forster $\mathrm{P}$, Röhl A. Median-joining networks for inferring intraspecific phylogenies. Mol Biol Evol. 1999;16(1):37-48.

Boyles JG, Cryan PM, McCracken GF, Kunz TH. Economic importance of bats in agriculture. Science. 2011;332(6025):41-2.

Brigham RM, Vonhof MJ, Barclay RMR, Gwilliam JC. Roosting behavior and roostsite preferences of forest-dwelling California bats (Myotis californicus). J Mammal. 1997;78:1230-9.

Broders HG, Forbes GJ, Woodley S, Thompson ID. Range extent and stand selection for roosting and foraging in forest-dwelling northern long-eared bats and little brown bats in the Greater Fundy Ecosystem. New Brunswick J Wildl Manage. 2006;70(5):1174-84.

Byeon SY, Jang JE, Choi HJ, Kim HR, Lee HJ. Genetic diversity and phylogenetic relationships of the greater horseshoe bat, Rhinolophus ferrumequinum, from national parks of Korea including the Baekdudaegan mountain range. J Natl Park Res. 2018;9(3):336-42.

Excoffier L, Lischer HE. Arlequin suite ver 3.5: a new series of programs to perform population genetics analyses under Linux and Windows. Mol Ecol Resour. 2010;10(3):564-7.

Faure PA, Re DE, Clare EL. Wound healing in the flight membranes of big brown bats. J Mammal. 2009;90(5):1148-56.

Fenton MB. Science and the conservation of bats. J Mammal. 1997:78(1):1-14.

Fenton MB. Science and the conservation of bats: where to next? Wild Soc Bull. 2003;31(1):6-15.

Irwin DM, Kocher TD, Wilson AC. Evolution of the cytochromeb gene of mammals. J Mol Evol. 1991;32(2):128-44.

Johnson LN, McLeod BA, Burns LE, Arseneault K, Frasier TR, Broders HG. Population genetic structure within and among seasonal site types in the little brown bat (Myotis lucifugus) and the northern long-eared bat ( $M$. septentrionalis). PloS One. 2015;10(5):e0126309.

Kawai K, Nikaido M, Harada M, Matsumura S, Lin LK, Wu Y et al. The status of the Japanese and East Asian bats of the genus Myotis Vespertilionidae) based on mitochondrial sequences. Mol Phylogenetics Evol. 2003:28(2):297-307.

Kim SS, Dai F, Han SH, Hur WH, Oh DS. Habitat characteristics of Myotis ikonnikovi. Korean J Ecol Environ. 2014;47(1):41-52.

Kruskop SV, Borisenko AV, Ivanova NV, Lim BK, Eger JL. Genetic diversity of northeastern Palaearctic bats as revealed by DNA barcodes. Acta Chiropt. 2012;14(1):1-14.

Kumar S, Stecher G, Tamura K. MEGA7: molecular evolutionary genetics analysis version 7.0 for bigger datasets. Mol Biol Evol. 2016;33(7):1870-4.

Kunz TH, Braun de Torrez E, Bauer D, Lobova T, Fleming TH. Ecosystem services provided by bats. Ann N Y Acad Sci. 2011;1223(1):1-38.

Kunz TH, Lumsden LF. Ecology of cavity and foliage roosting bats. In: Kunz TH, Fenton MB, editors. Bat ecology. Chicago: University of Chicago Press; 2003. p. 3-89.

Kurta A, Williams KJ, Mies R. Ecological, behavioral, and thermal observations of a peripheral population of Indiana bats (Myotis sodalis). In: Barclay RMR, Brigham RM, editors. Bats and forests symposium. Victoria: British Columbia Ministry of Forests; 1996. p. 102-17.

Lewis SE. Roost fidelity of bats: a review. J Mammal. 1995;76:481-96.

Librado P, Rozas J. DnaSP v5: a software for comprehensive analysis of DNA polymorphism data. Bioinformatics. 2009;25(11):1451-2.

Menzel MA Owen SF, Ford WM, Edwards JW, Wood PB, Chapman BR, Miller KV. Roost tree selection by northern long-eared bat (Myotis septentrionalis) maternity colonies in an industrial forest of the central Appalachian Mountains. For Ecol Manag. 2002;155:107-14. 
Moussy C, Atterby H, Griffiths A, Allnutt T, Mathews F, Smith G, et al. Population genetic structure of serotine bats (Eptesicus serotinus) across Europe and implications for the potential spread of bat rabies (European bat lyssavirus EBLV-1). Heredity. 2015;115(1):83-92.

Ormsbee PC. Characteristics, use, and distribution of day-roosts selected by female Myotis volans (long-legged myotis) in forested habitat of the Central Oregon Cascades. In: Barclay RMR, Brigham RM, editors. Bats and forests symposium. Victoria: British Columbia Ministry of Forests; 1996. p. 124-31.

Razgour O, Juste J, Ibáñez C, Kiefer A, Rebelo H, Puechmaille SJ, et al. The shaping of genetic variation in edge-of-range populations under past and future climate change. Ecol Lett. 2013;16(10):1258-66.

Rossiter SJ, Jones G, Ransome RD, Barratt EM. Genetic variation and population structure in the endangered greater horseshoe bat Rhinolophus ferrumequinum. Mol Ecol. 2000;9(8):1131-5.

Ruedi M, Castella V. Genetic consequences of the ice ages on nurseries of the bat Myotis myotis: a mitochondrial and nuclear survey. Mol Ecol. 2003;12(6): $1527-40$.

Schipper J, Chanson JS, Chiozza F, Cox NA, Hoffmann M, Katariya V, et al. The status of the world's land and marine mammals: diversity, threat, and knowledge. Science. 2008;322(5899):225-30

Simmons NB. Chiroptera. In: Wilson DE, Reeder DAM, editors. Mammal species of the world: a taxonomic and geographic reference. Baltimore: Johns Hopkins University Press; 2005. p. 312-529.

Szpiech ZA, Jakobsson M, Rosenberg NA. ADZE: a rarefaction approach for counting alleles private to combinations of populations. Bioinformatics. 2008; 24:2498-504.

Vrijenhoek R. DNA primers for amplification of mitochondrial cytochrome c oxidase subunit I from diverse metazoan invertebrates. Mol Mar Biol Biotechnol. 1994;3(5):294-9.

Wright PG, Hamilton PB, Schofield H, Glover A, Damant C, Davidson-Watts I, Mathews F. Genetic structure and diversity of a rare woodland bat, Myotis bechsteinii: comparison of continental Europe and Britain. Conserv Genet. 2018:19(4):777-87.

\section{Publisher's Note}

Springer Nature remains neutral with regard to jurisdictional claims in published maps and institutional affiliations.

Ready to submit your research? Choose BMC and benefit from:

- fast, convenient online submission

- thorough peer review by experienced researchers in your field

- rapid publication on acceptance

- support for research data, including large and complex data types

- gold Open Access which fosters wider collaboration and increased citations

- maximum visibility for your research: over $100 \mathrm{M}$ website views per year

At $\mathrm{BMC}$, research is always in progress.

Learn more biomedcentral.com/submissions 